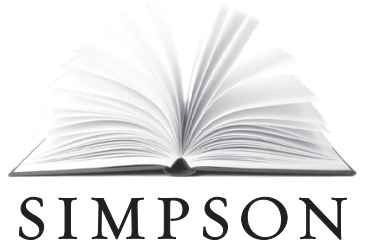

IMPRINT IN HUMANITIES

The humanities endowment

by Sharon Hanley Simpson and

Barclay Simpson honors

MURIEL CARTER HANLEY

whose intellect and sensitivity

have enriched the many lives

that she has touched. 
The publisher gratefully acknowledges the generous support of the Simpson Humanities Endowment Fund of the University of California Press Foundation, which was established by a major gift from Barclay and Sharon Simpson. 
The Road Out 
This page intentionally left blank 


\title{
The Road Out
}

A Teacher's Odyssey in

Poor America

\author{
Deborah Hicks
}

\section{甲}

UNIVERSITY OF CALIFORNIA PRESS

Berkeley Los Angeles London 
University of California Press, one of the most distinguished university presses in the United States, enriches lives around the world by advancing scholarship in the humanities, social sciences, and natural sciences.

Its activities are supported by the UC Press Foundation and by philanthropic contributions from individuals and institutions.

For more information, visit www.ucpress.edu.

\author{
University of California Press \\ Berkeley and Los Angeles, California \\ University of California Press, Ltd. \\ London, England \\ (C) 2013 by Deborah Hicks
}

Library of Congress Cataloging-in-Publication Data

Hicks, Deborah.

The road out : a teacher's odyssey in poor America /

Deborah Hicks.

p. $\mathrm{cm}$.

Includes bibliographical references and index.

ISBN 978-0-520-26649-o (cloth : alk. paper)

I. Poor [low income?] girls-Education-Ohio-

Cincinnati. 2. Poor whites-Education-Ohio-

Cincinnati. 3. Poor girls-Books and reading-Ohio-

Cincinnati. 4. Poor girls-Ohio-Cincinnati-

Anecdotes. Hicks, Deborah-Anecdotes. I. Title.

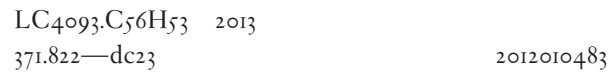

Manufactured in the United States of America

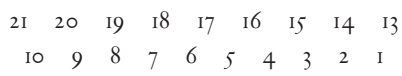

In keeping with a commitment to support environmentally responsible and sustainable printing practices, UC Press has printed this book on Natures Book, a fiber that contains $30 \%$ postconsumer waste and meets the minimum requirements of ANSI/NISO Z39.48-I992 (R I997) (Permanence of Paper). 
I want to be lifted up

By some great white bird unknown to the police, And soar for a thousand miles and be carefully hidden Modest and golden as one last corn grain, Stored with the secrets of the wheat and the mysterious lives

Of the unnamed poor.

James Wright, "The Minneapolis Poem," Shall We Gather at the River 
This page intentionally left blank 